\title{
Determination of Target Pesticide Residues in Tropical Fruits Employing Matrix Solid-Phase Dispersion (MSPD) Extraction Followed by High Resolution Gas Chromatography
}

\author{
Silvia S. Freitas, ${ }^{a, b}$ Felipe A. T. Serafim ${ }^{a}$ and Fernando M. Lanças $* a$ \\ anstituto de Química, Universidade de São Paulo, Av. Trabalhador São-carlense 400, \\ 13560-970 São Carlos-SP, Brazil \\ ${ }^{b}$ Departamento de Química, Universidade Federal de Goiás, Campus Catalão, \\ Av. Dr. Lamartine Pinto de Avelar 1120, 75700-000 Catalão-GO, Brazil
}

\begin{abstract}
A simple method based on matrix solid-phase dispersion (MSPD) extraction and gas chromatography with electron-capture detection (GC-ECD) is employed to determine pesticide residues in the following tropical fruits: banana, mango, melon, papaya and pineapple. In the MSPD proposed method, C18, silica gel and ethyl acetate presented the best results in the extraction, clean-up and elution steps, respectively. Spiked blank samples were used to minimize the matrix effect in the chromatographic determination. The validation process was conducted at three different concentration levels of spiked samples $\left(0.50-2.50 \mu \mathrm{g} \mathrm{g}^{-1}\right)$ in within-a-day and in among days assays. The limits of detection for the pesticides ranged from 4.0 to $23 \mu \mathrm{g} \mathrm{kg}^{-1}$. The method showed acceptable selectivity, coefficients of correlation higher than 0.997 , and recovery between 76-105\%. The within-a-day precision was assessed through the relative standard deviation $(2.8-19 \%)$ for the different levels of spiked samples tested.
\end{abstract}

Keywords: matrix solid-phase dispersion, pesticide residues, method validation, GC-ECD

\section{Introduction}

The recent Brazilian fruit growing jumped the country to an important position in the international agribusiness sector. In 2015, Brazil set a record in fruit exports with a total fresh fruit sales achieving US\$ 735 million, a performance around US\$ 100 million higher than 2014. With a variety of crops produced throughout the country and in different climates, Brazil is the leading world producer of oranges; the secondleading producer of bananas and papayas; the third-largest producer of pineapples; and an important producer of Tahiti lemons, tangerines and grapes. ${ }^{1}$

Brazil is, after China and India, the third largest producer of fruit in the world (43 million ton per year). About $70 \%$ of Brazil's fruit exports go to Europe and the overarching goal of Brazilian fruit cultivation is to consolidate its position as the leader in the international market. Approximately 711,000 tons of the Brazilian fruits are exported to more than 110 countries being mangoes, melons, oranges, grapes, papayas, limes and bananas the

*e-mail: flancas@iqsc.usp.br main fruits exported in 2014. According to the Brazilian association of producers and exporters of fruit, the country has conditions to reach US\$ 1 billion in exports of fresh fruit by 2017 if it can conform to international phytosanitary and customs conditions through better control of domestic production. ${ }^{1}$

The international market has strongly signaled that there is a movement of consumers looking for healthy food and without agrochemical residues considered to be harmful to human health. The European Community, mainly, have required that the exporters take into account the respect with the environment, traceability and working conditions, health of workers involved in food production and level of pesticide residues.

The European Union and the United Kingdom banned mangoes imported from India until the country meets the phytosanitary standards that will ensure they are pest-free. ${ }^{2,3}$ The entrance of cherries from countries, where the use of the chemical dimethoate is legal, was recently prohibited in France. ${ }^{4}$

Regarding to the Brazilian domestic market, local consumers are concerned with the food safety and 
quality, once the overall care taken with the exported fruits rarely are the same as that taken when dealing with the locally distributed ones. The use of pesticides in households and in agriculture is a common practice wide spread nowadays. As a consequence, strict control of their presence is necessary to protect the consumer from the harmful impact of pesticide residues. According to the World Trade Organization, ${ }^{5}$ which contributes to the safety, quality and fairness of this international food trade, many countries present different maximum residue limits (MRLs) for pesticides from those informed in the Codex Alimentarius. This suggests that these are striving to develop their proper phytosanitary laws, since pesticide regulation in the world is a slow and complicated process. ${ }^{6}$ The status of pesticide approvals is continually changing as many of the older generation pesticides developed in the past century are under review, while newer products are appearing all the time.

Among the various pesticides classes, the organophosphorus (OPPs) and the isophtalonitriles together comprise over half of all pesticides used worldwide, mainly in the Brazilian fruits crops. OPPs are the pesticide class most widely used in the food crops and present dangerous toxicological and ecotoxicological effects to human health, although levels detected in edible crops and food animals have been far below the acceptable daily intake. ${ }^{7-11}$ Compared to the organochlorine pesticides (mostly banned in USA and Europe), the OPPs ones are less persistent in the environment and are not subject of bioaccumulation. ${ }^{12}$ Therefore, among the toxic effects associated with organophosphate stands out neurotoxicity, immunotoxicity, carcinogenicity and endocrine disruption. For example, parathion methyl was banned from Brazilian, Chinese and Japanese markets since it present irreversible inhibitors of acetylcholinesterase, leading to toxic effects on the nervous system. ${ }^{13}$ Fenitrothion, other organophosphate pesticide, is far less toxic than parathion with a range of insecticidal activity that is very similar and is used in the fruits crops with controlled levels. Though fenitrothion does not present cumulative proprieties in the food chain, it can inhibit the function of acetylcholinesterase, an enzyme required for the normal function of nervous system. ${ }^{14}$ Dimethoate is an insecticide widely used in most countries and presents a particular concern once, besides being toxic, it has potential links to carcinogenic properties. ${ }^{15}$ Diazinon is used throughout the world to protect a wide range of crops, including fruit trees, citrus fruit, bananas, vegetables, potatoes, beet, sugar cane, coffee, cocoa, tea, tobacco, cotton, and rice. Due to its neurotoxicity effect and data gaps, UK government regulators are increasingly likely to restrict its use, although the report of World
Health Organization found no evidence of embryotoxic or teratogenic potential, adverse effects on reproduction function, or carcinogenic action and, therefore, does not pose a significant health hazard for the general population. ${ }^{16-18}$

Chlorothalonil (2,4,5,6-tetrachloroisophthalonitrile), the most known isophtalonitrile, has a broad spectrum, nonsystemic foliar fungicide used extensively to control fungal and bacterial infestation. Although there is no indication that it is a human carcinogen, there are evidences from animal studies to classify it as a potential carcinogen. ${ }^{19,20}$

According to the Agropages ${ }^{21} 22$ of the 50 pesticides most used in Brazilian crops are banned in several other countries. ${ }^{22,23}$ Thus, to the effective expansion of Brazilian fruits exports to major consumers markets and to ensure regulated fruit input under Brazilian law, the country should focus on the development of simple and effective analytical methodologies that agree with the requirements set by the global markets.

Pesticide residue analysis requires techniques that should be sensitive, selective, accurate, precise, cheap and applicable to as many compounds as possible, with only a few extraction and clean-up steps. ${ }^{19,20,22,23}$

Numerous analytical methods for pesticides determination in fruits and other complex food matrices have been described in the literature and in official protocols. The most frequently used in practice are gas chromatography (GC) with different selective detectors like electron-capture (ECD), ${ }^{24-27}$ nitrogen-phosphorus (NPD) ${ }^{28,29}$ and mass spectrometric detection (GC-MS), ${ }^{30-32}$ as well high performance liquid chromatography (HPLC) with diodearray detection (DAD), ${ }^{33}$ and fluorescence detection. ${ }^{34}$

In quantitative analysis, sample preparation is essential to isolate target compounds from the matrix by using a correct and efficient method, which represents an analytical challenge. Classical sample preparation procedures for pesticide analysis in food matrices usually involve liquidliquid extraction. ${ }^{35,36}$ With the miniaturization trends in sample preparation, several new methods have been proposed, such as solid-phase microextraction (SPME), ${ }^{37,38}$ stir bar sorptive extraction (SBSE), ${ }^{39,40}$ matrix solid phase dispersion (MSPD) ${ }^{41-46}$ among others, that offer advantages in the sample preparation procedure as minimization in the use of hazardous solvents, generate little waste and reduce time, space and glassware required for extraction. ${ }^{37-46}$

MSPD is a simple and robust alternative to sample preparation. ${ }^{41-46}$ In this technique, small quantities of the solid samples, as fruits, are dispersed on a sorbent in a mortar and placed on cartridges for the pesticides extraction with small amount of organic solvents. ${ }^{41-46}$ Depending on the nature of the sorbent selected, the extraction and clean-up 
steps occur simultaneously, allowing the direct analysis of the collected extracts. ${ }^{41-46}$

This work proposes a simple and efficient analytical method based on the separation and quantitation of five relevant pesticides (chlorothalonil, dimethoate, diazinon, fenitrothion and parathion methyl) used in tropical fruit crops such as banana, mango, melon, papaya and pineapple. For this purpose, matrix solid phase dispersion (MSPD) was used for the extraction and clean-up steps, followed by gas chromatography with electron capture detection (GC-ECD). Confirmation of the pesticides identity was done by gas chromatography coupled to mass spectrometry (GC-MS).

\section{Experimental}

\section{Reagents}

Analytical grade pesticide standards (dimethoate, diazinon, chlorothalonil, parathion methyl, fenitrothion), each with more than $98 \%$ purity, were obtained from Chem Service (West Chester, USA). Acetonitrile, dichloromethane, $n$-hexane, methanol and ethyl acetate were supplied by Mallinckrodt (Phillipsburg, USA). The solid-phase materials employed were: octadecyl silica C18 (15-25 $\mu \mathrm{m})$ and celite (acid washed) from Alltech (Deerfield, USA); silica gel 60 (70/230 mesh), neutral alumina (70/230 mesh), microcrystalline cellulose from E. M. Merck (Darmstadt, Germany) and Florisil (60/100 mesh) from Supelco (Bellefonte, USA). All adsorbents were washed with ethyl acetate (reagent grade) before use.

The following apparatus were used: a domestic food processor; porcelain capsule and glass pestle; 12-port vacuum manifold (Visiprep DL ${ }^{\mathrm{TM}}$, São Paulo, Brazil), from Supelco (São Paulo, Brazil); and a vortex (Mistral, LabLine, São Paulo, Brazil). Extraction columns were prepared from polypropylene empty solid-phase extraction cartridges (15 mL capacity), containing a $20 \mu \mathrm{m}$ polyethylene frit.

\section{Samples}

Banana, mangoes, melons, papaya and pineapple were selected based upon their production and consumption volume. Fruit samples, used for blank and fortified studies, were obtained in a local market. The seeds of the papaya and melon, the mango core and the crown of the pineapple were removed. In the banana case, the whole fruit was analyzed. Each fruit was then crushed using a household processor and stored in a freezer until analysis. The absence of examined residues was checked by GC-MS screening of respective extracts (GC-MS section).

\section{Chromatographic conditions}

\section{GC-ECD}

A gas chromatograph (Shimadzu GC-17A, Kyoto, Japan) equipped with a ${ }^{63} \mathrm{Ni}$ electron-capture detector (Shimadzu ECD-17, Kyoto, Japan) was used for the pesticides analysis. A fused silica capillary column (5\% phenyl methylpolysiloxane stationary phase), $30 \mathrm{~m} \times 0.25 \mathrm{~mm}$ i.d. and $0.30 \mu \mathrm{m}$ film thickness (statically coated in our laboratory), was employed. Injector was operated in splitless mode $(0.7 \mathrm{~min})$ at $250{ }^{\circ} \mathrm{C}$. Oven temperature was programmed as follows: the initial temperature of $100{ }^{\circ} \mathrm{C}(0.8 \mathrm{~min})$ was increased at $20^{\circ} \mathrm{C} \mathrm{min}^{-1}$ to $290{ }^{\circ} \mathrm{C}$ and was held for $1.7 \mathrm{~min}$. Hydrogen (ultra pure (UP) grade) was used as carrier gas at a flow-rate of $1.5 \mathrm{~mL} \mathrm{~min}^{-1}$. Nitrogen (UP grade) was used as make up gas at a flow rate of $20 \mathrm{~mL} \mathrm{~min}^{-1}$. The ECD temperature was set at $300{ }^{\circ} \mathrm{C}$. A volume of $1 \mu \mathrm{L}$ of each standard solution or sample extract was injected into the GC system.

\section{GC-MS}

Preliminarily, the fruits blank extracts were analyzed in a GC-MS system, equipped with a selective mass detector (Shimadzu, MSD QP 5000, Kyoto, Japan) to be sure that they were absent of the target pesticides. Helium $(99.995 \%)$ was used as the carrier gas at a flow rate of $1.0 \mathrm{~mL} \mathrm{~min}^{-1}$. The mass spectrometer was operated in the electron ionization mode (EI, $70 \mathrm{eV}$ ) being the temperature of the transfer line set to $280^{\circ} \mathrm{C} .1 \mu \mathrm{L}$ of each standard solution or sample blank extract was injected. Analysis was carried out in the selected ion monitoring (SIM) mode. For each compound, three selected ions $(\mathrm{m} / \mathrm{z})$ were monitored: dimethoate (87, 93, and 125), diazinon (137, 152, and 179), chlorothalonil (264, 266, and 268), parathion methyl $(109,125$, and 263) and fenitrothion $(109,125$, and 277). The most abundant ion was selected for quantification in each case.

\section{Matrix solid-phase dispersion extraction procedure}

\section{Preparation of the fruits samples}

Fruit samples were ground, using a domestic food processor, and kept in a freezer at $-20{ }^{\circ} \mathrm{C}$. All banana parts were analyzed. The seeds of the papaya and melon, the stone of the mango and the crown of pineapple were removed. For the MSPD procedure, an aliquot of the sample $(0.5 \mathrm{~g})$ was gently blended with $0.5 \mathrm{~g}$ of dispersion sorbent into a porcelain capsule using a glass pestle, until a homogeneous mixture was obtained. This was introduced into a polypropylene cartridge (extraction column) with the dispersed matrix, which was linked with another one 
containing $0.5 \mathrm{~g}$ of the clean-up sorbent at the bottom. After, ethyl acetate was added to the first column and the sample was allowed to elute dropwise by applying a slight vacuum, so that the eluent of the MSPD were simultaneously purified in a single process. The extract was collected in a volumetric flask $(5.0 \mathrm{~mL})$ and the volume completed with ethyl acetate according to the Figure 1. An aliquot $(500 \mu \mathrm{L})$ of the blank fruit extract was transferred to an Eppendorf type flask and dried under a gentle nitrogen stream. Before the chromatographic analysis, the extract was reconstituted with $50 \mu \mathrm{L}$ of ethyl acetate. $1 \mu \mathrm{L}$ of each extract solution was analyzed in the chromatographic system.

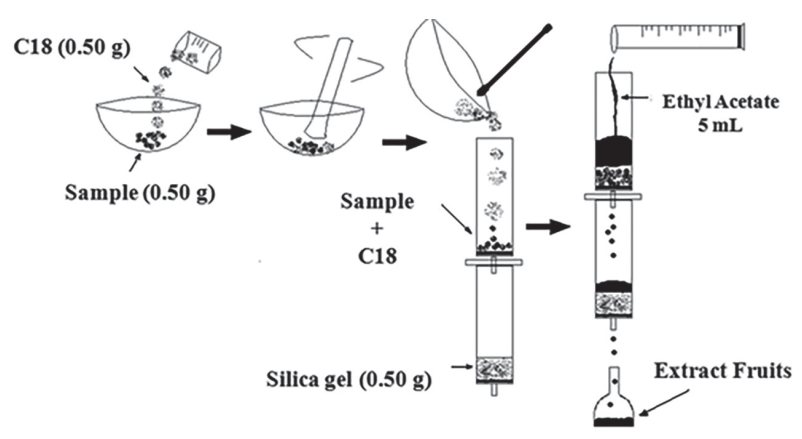

Figure 1. General schematics of the matrix solid phase dispersion (MSPD) extraction approach utilized in this work.

For the analytical curves prepared in fruit matrix, eight standard mixture solutions, each one containing the five pesticides in the same concentration, were prepared as a calibration set, at concentrations of $0.05,0.1,0.2,0.5$, $1.0,1.5,2.0$ and $2.5 \mu \mathrm{g} \mathrm{g}^{-1}$. This concentration range was chosen on the basis of the MRLs allowed in fruits for such pesticide in the studied commodities. ${ }^{47}$

\section{Fortified samples extraction}

An appropriate volume of the standard mixture, prepared in ethyl acetate as described before, was added to $0.5 \mathrm{~g}$ of the blank sample. The fortified samples were allowed to stand at room temperature for about $15 \mathrm{~min}$. After, the extraction procedure was performed as described in the previous section.

\section{Method validation}

To validate the analytical MSPD/GC-ECD method proposed, some factors were carried out according to the procedures and acceptation criterions recommended for pesticides residues and conducted to determine the selectivity, linearity, accuracy, precision, limit of detection (LOD) and limit of quantification (LOQ) in bananas, mangoes, melons, papayas and pineapples samples. ${ }^{48-51}$
The linearity in the pesticide response was studied by using matrix-matched calibration standards. For each pesticide, the analytical curve based on peak area was evaluated at a concentration range from 0.05 to $2.50 \mu \mathrm{g} \mathrm{g}^{-1}$ for diazinon and dimethoate; 0.05 to $1.0 \mu \mathrm{g} \mathrm{g}^{-1}$ for chlorothalonil; and 0.05 to $2.0 \mu \mathrm{g} \mathrm{g}^{-1}$ for parathion methyl and fenitrothion, including eight concentration levels. Each concentration level was analyzed in triplicate. The calibration parameters (correlation coefficient, $r$, and regression equation) were obtained by linear regression.

The limits of detection (LOD) were assessed by consecutive analysis of standard mixtures solutions prepared in blank sample extract containing the investigated pesticides in decreasing concentrations. For each pesticide, the LOD was determined as the lowest concentration giving a response three-time higher than that any endogenous compounds present in the blank extract on the investigated pesticide retention time.

The limit of quantification (LOQ) was determined as the lowest pesticide amount assayed giving a response that can be quantified with acceptable accuracy and precision.

\section{Results and Discussion}

The resulting correlation coefficients were higher than 0.997 in all cases, proving favorable linear detector response for all pesticides in the concentration range studied (Table 1). Because different LOD values were obtained for the investigated pesticides $\left(4-25 \mu \mathrm{g} \mathrm{kg}^{-1}\right)$, $50 \mu \mathrm{g} \mathrm{kg}^{-1}$ was assumed as the LOQ for all pesticides on the proposed method. Although this conservative assumed value seems to be high, it indeed contemplates the maximum residue limit (MRL) in fruits according to the Brazilian Pesticide Residue Monitoring Program guidelines (Table 1). ${ }^{47}$

The accuracy and precision (within-a-day and among days) were assessed by recovery tests done with fruits samples fortified at three concentration levels $(0.05 ; 0.50$ and $1.0 \mu \mathrm{g} \mathrm{g}^{-1}$ ), see Table 2. For within-a-day, five recovery assays were done in a single day for each pesticide, at each concentration level, the results being obtained under the same conditions (same analyst, apparatus, reagents and short interval of time). The accuracy was determined as mean recovery. A total of 75 recovery assays were done (including the three levels and the five pesticides studied). The within-a-day precision (repeatability) was assessed through the relative standard deviation (RSD) of the recovery results obtained. The mean recoveries observed within-a-day were between $76-105 \%$ and repeatability between $2.8-19.8 \%$. The results related to the method accuracy and precision were obtained from the analysis 
Table 1. Validation parameters: linearity range, correlation coefficient (r), limit of detection (LOD), limit of quantification (LOQ) and recovery for all investigated pesticides as obtained by the MSPD-GC-ECD method and maximum limit of residues (MRL)

\begin{tabular}{|c|c|c|c|c|c|c|}
\hline & $\begin{array}{l}\text { Linearity range / } \\
\qquad\left(\mu \mathrm{g} \mathrm{g}^{-1}\right)\end{array}$ & $\begin{array}{l}\text { Correlation } \\
\text { coefficient }\end{array}$ & $\mathrm{LOD} /\left(\mu \mathrm{g} \mathrm{kg}^{-1}\right)$ & $\mathrm{LOQ} /\left(\mu \mathrm{g} \mathrm{kg}^{-1}\right)$ & Recovery / \% & $\mathrm{MRL}^{\mathrm{a}} /\left(\mu \mathrm{gg}^{-1}\right)$ \\
\hline \multicolumn{7}{|c|}{ Papaya } \\
\hline Chlorothalonil & $0.05-1.00$ & 0.997 & 10 & 50 & 72 & 100 \\
\hline Diazinon & $0.05-2.50$ & 0.997 & 5.0 & 50 & 93 & n.a \\
\hline Dimethoate & $0.05-2.50$ & 0.996 & 15 & 50 & 86 & n.a \\
\hline Fenitrothion & $0.05-2.00$ & 0.989 & 20 & 50 & 77 & n.a \\
\hline Parathionmethyl & $0.05-2.00$ & 0.995 & 5.0 & 50 & 744 & n.a \\
\hline \multicolumn{7}{|c|}{ Melon } \\
\hline Chlorothalonil & $0.05-1.00$ & 0.998 & 5.0 & 50 & 93 & 100 \\
\hline Diazinon & $0.05-2.50$ & 0.991 & 6.0 & 50 & 93 & n.a \\
\hline Dimethoate & $0.05-2.50$ & 0.994 & 15 & 50 & 110 & n.a \\
\hline Fenitrothion & $0.05-2.00$ & 0.990 & 25 & 50 & 75 & n.a \\
\hline Parathionmethyl & $0.05-2.00$ & 0.997 & 5.0 & 50 & 1084 & n.a \\
\hline \multicolumn{7}{|c|}{ Banana } \\
\hline Chlorothalonil & $0.05-1.00$ & 0.999 & 5.0 & 50 & 97 & 3000 \\
\hline Diazinon & $0.05-2.50$ & 0.990 & 5.0 & 50 & 102 & n.a \\
\hline Dimethoate & $0.05-2.50$ & 0.991 & 15 & 50 & 90 & n.a \\
\hline Fenitrothion & $0.05-2.00$ & 0.997 & 20 & 50 & 105 & n.a \\
\hline Parathionmethyl & $0.05-2.00$ & 0.992 & 5.0 & 50 & 105 & n.a \\
\hline \multicolumn{7}{|c|}{ Mango } \\
\hline Chlorothalonil & $0.05-1.00$ & 0.999 & 10 & 50 & 74 & n.a \\
\hline Diazinon & $0.05-2.50$ & 0.994 & 10 & 50 & 719 & n.a \\
\hline Dimethoate & $0.05-2.50$ & 0.991 & 15 & 50 & 71 & n.a \\
\hline Fenitrothion & $0.05-2.00$ & 0.999 & 20 & 50 & 80 & n.a \\
\hline Parathionmethyl & $0.05-2.00$ & 0.991 & 5.0 & 50 & 71 & n.a \\
\hline \multicolumn{7}{|c|}{ Pineapple } \\
\hline Chlorothalonil & $0.05-1.00$ & 0.996 & 10 & 50 & 91 & n.a \\
\hline Diazinon & $0.05-2.50$ & 0.990 & 10 & 50 & 88 & n.a \\
\hline Dimethoate & $0.05-2.50$ & 0.990 & 15 & 50 & 89 & n.a \\
\hline Fenitrothion & $0.05-2.00$ & 0.993 & 20 & 50 & 78 & n.a \\
\hline Parathionmethyl & $0.05-2.00$ & 0.992 & 5.0 & 50 & 90 & n.a \\
\hline
\end{tabular}

${ }^{a}$ Maximum residue level; n.a: not available; LOD: limit of detection; LOQ: limit of quantification.

during five consecutive days at each concentration level. The mean recovery results are in the range of $79-98 \%$ with RSD values between $6.5-17.5 \%$ (Table 2). All the results are in agreement with the acceptance criterion suggested for pesticides residues analysis.

Figure 2 shows the differences in the chromatographic profile obtained when different fruit extracts were spiked (at $0.50 \mu \mathrm{g} \mathrm{g}^{-1}$ ) with a standard solution containing the target pesticides. Due to the complexity of the matrices studied, the analytical curves were constructed in the extracts of the white matrix, which allowed the acquisition of more accurate results as described by our group in an earlier publication. ${ }^{52}$

The use of polar sorbents, i.e., florisil $\left[\mathrm{Mg} . \mathrm{Al}\left(\mathrm{SO}_{4}\right)_{\mathrm{n}}\right]$ and silica gel $\left[\left(\mathrm{SiO}_{2}\right)_{\mathrm{n}}-\mathrm{OH}\right]$ as dispersant, gave clean extracts with a minimum of ECD-sensitive compounds which did not interfere with the pesticides. However, the higher adsorption strength of these sorbents gave unsatisfactory recoveries values (40 to 70\%). Non-polar phase sorbents such as $\mathrm{C} 18\left[(\mathrm{Si})_{\mathrm{n}}-\left(\mathrm{CH}_{2}\right)_{17}-\mathrm{CH}_{3}\right]$ produced large quantities of interferences. In addition, the hydrophobic surface of C18 could not retain the target compounds, which were 
Table 2. Average recovery values (Rm) and its relative standard deviation (RSD) obtained in the within-a-day and between day assays for the target pesticides, employing the proposed MSPD/GC-ECD method ( $\mathrm{n}=5$ for each pesticide at each concentration level)

\begin{tabular}{|c|c|c|c|c|c|c|c|c|c|c|c|c|}
\hline \multirow{3}{*}{ Pesticide } & \multicolumn{6}{|c|}{ Within-a-day } & \multicolumn{6}{|c|}{ Among days } \\
\hline & \multicolumn{2}{|c|}{$0.05 \mu \mathrm{g} \mathrm{g}^{-1}$} & \multicolumn{2}{|c|}{$0.50 \mu \mathrm{g} \mathrm{g}^{-1}$} & \multicolumn{2}{|c|}{$1.00 \mu \mathrm{g} \mathrm{g}^{-1}$} & \multicolumn{2}{|c|}{$0.05 \mu \mathrm{g} \mathrm{g}^{-1}$} & \multicolumn{2}{|c|}{$0.50 \mu \mathrm{g} \mathrm{g}^{-1}$} & \multicolumn{2}{|c|}{$1.00 \mu \mathrm{g} \mathrm{g}^{-1}$} \\
\hline & $\mathrm{Rm} / \%$ & $\mathrm{RSD} / \%$ & $\mathrm{Rm} / \%$ & $\mathrm{RSD} / \%$ & $\mathrm{Rm} / \%$ & $\mathrm{RSD} / \%$ & $\mathrm{Rm} / \%$ & $\mathrm{RSD} / \%$ & $\mathrm{Rm} / \%$ & $\mathrm{RSD} / \%$ & $\mathrm{Rm} / \%$ & RSD / \% \\
\hline Dimethoate & 76 & 19.8 & 86 & 14.1 & 89 & 10.4 & 85 & 12.6 & 80 & 9.7 & 98 & 12.6 \\
\hline Diazinon & 105 & 2.8 & 88 & 3.6 & 86 & 8.3 & 85 & 6.7 & 91 & 13.3 & 95 & 7.7 \\
\hline Chlorothalonil & 86 & 17.7 & 97 & 7.1 & 92 & 4.5 & 89 & 13.0 & 98 & 7.1 & 89 & 8.1 \\
\hline Parathion methyl & 90 & 19.8 & 97 & 10.3 & 93 & 8.3 & 90 & 15.5 & 97 & 14.9 & 94 & 13.9 \\
\hline Fenitrothion & 80 & 17.3 & 96 & 4.2 & 81 & 7.7 & 79 & 17.5 & 98 & 14.7 & 94 & 6.5 \\
\hline
\end{tabular}

Rm: average recovery value; RSD: relative standard deviation.
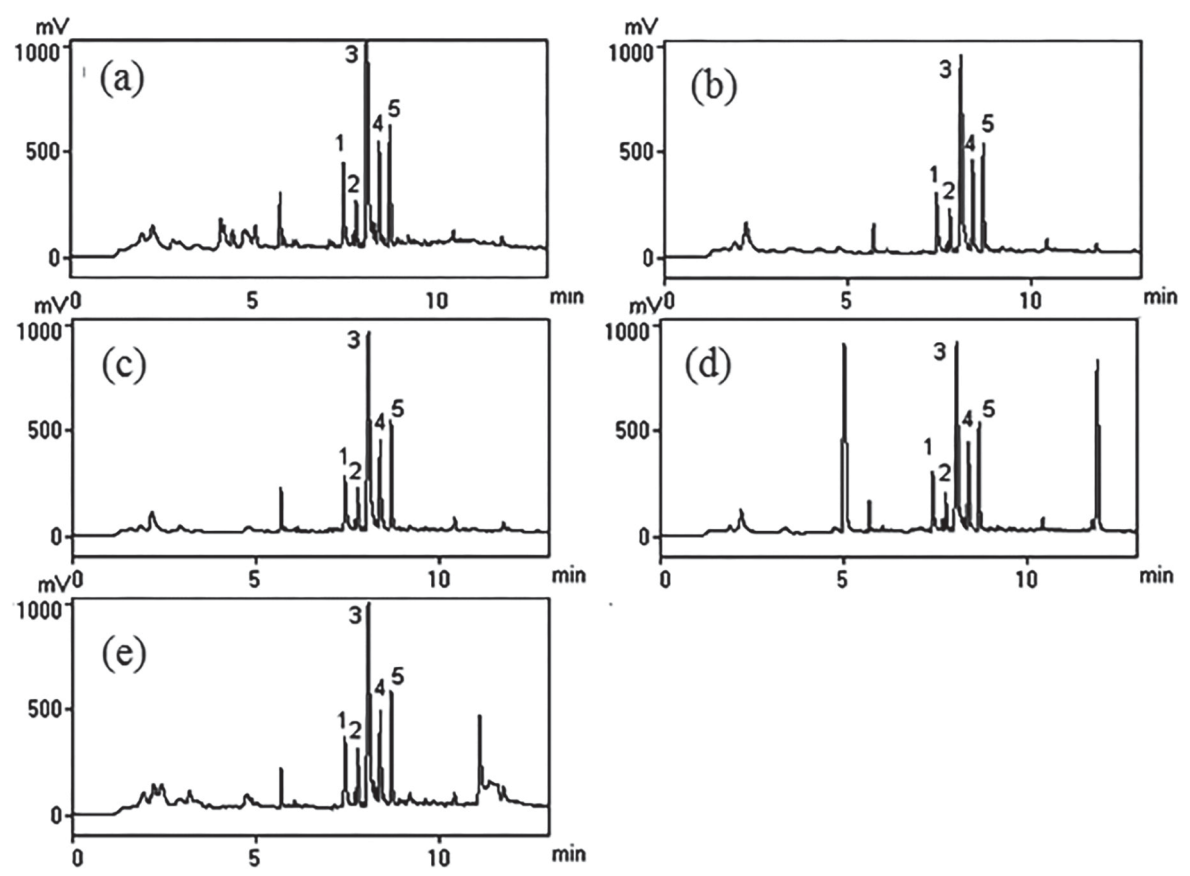

Figure 2. GC-ECD chromatograms obtained from the extracts of (a) banana; (b) mango; (c) melon; (d) papaya; (e) pineapple, spiked with pesticides at $0.50 \mu \mathrm{g} \mathrm{mL}{ }^{-1}$ (1: dimethoate; 2: diazinon; 3: clorothalonil; 4: parathion methyl; 5: fenitrothion).

eluted with the solvent (ethyl acetate). However, this problem was solved by adding up a clean-up step to the method.

As a result, $\mathrm{C} 18$ was used as solid phase material for dispersion, and silica gel, florisil, alumina $\left[\left(\mathrm{Al}_{2} \mathrm{O}_{3}\right)_{\mathrm{n}}\right]$, celite (diatomaceous earth) and cellulose microcrystalline $\left[\left(\mathrm{C}_{6} \mathrm{H}_{10} \mathrm{O}_{5}\right)_{n}\right]$ were tested as sorbents in the clean-up step. The results show that silica gel, florisil and alumina provided the cleanest extracts due to their high adsorption strength, which retain strongly the polar endogenous matrix compounds. The recovery values (Table 3 ) obtained for C18/cellulose were lower than that obtained with the other sorbents, probably due to the better affinity of the pesticides with the cellulose.

Considering the recovery interval accepted by most regulatory agencies $(70-120 \%)$, the results contained in Table 3 showed that C18/cellulose sorbent presented unsatisfactory results for diazinon and dimethoate. C18/celite presented unsatisfactory results for dimethoate. For chlorothalonil, fenitrothion and parathion methyl, all sorbents studied may be employed.

Different solvents (ethyl acetate, dichloromethane and hexane), and mixtures between them, were evaluated for pesticides elution from the MSPD column. The pesticides recovery was low (16-63\%) when the elution was made with dichloromethane. Neither pesticide was recovered when hexane was used. The recovery values with hexane/ ethyl acetate $(1: 1 \mathrm{v} / \mathrm{v})$ were between 62 and $72 \%$, with the exception of dimethoate. Besides the lower recovery, the extracts obtained with these solvents of smaller polarity than ethyl acetate, showed a great quantity of interfering compounds. Ethyl acetate was the solvent that promoted 
Table 3. Influence of sorbents, solvent of elution and elution volume in the extraction of target pesticides from different fruits (expressed as mean recovery values)

\begin{tabular}{|c|c|c|c|c|c|c|}
\hline & \multicolumn{6}{|c|}{ Recovery / \% } \\
\hline & Chlorothalonil & Diazinon & Dimethoate & Fenitrothion & Parathion methyl & Mean \\
\hline \multicolumn{7}{|l|}{ Adsorbent (clean-up) } \\
\hline C18/alumina & 90 & 80 & 82 & 90 & 91 & 87 \\
\hline C18/florisil & 79 & 77 & 83 & 80 & 71 & 78 \\
\hline C18/celite & 123 & 118 & 61 & 86 & 92 & 96 \\
\hline C18/cellulose & 75 & 60 & 63 & 78 & 70 & 69 \\
\hline C18/Silica gel & 110 & 96 & 99 & 105 & 102 & 102 \\
\hline \multicolumn{7}{|l|}{ Solvent } \\
\hline Dichloromethane & 55 & 19 & 16 & 63 & 53 & 41 \\
\hline Ethyl acetate & 102 & 80 & 82 & 94 & 98 & 91 \\
\hline Ethyl acetate/hexanoate $(1: 1 \mathrm{v} / \mathrm{v})$ & 62 & 72 & 53 & 70 & 72 & 66 \\
\hline \multicolumn{7}{|l|}{ Volume / mL } \\
\hline 1.0 & 22 & 21 & 18 & 26 & 23 & 22 \\
\hline 2.0 & 94 & 90 & 58 & 100 & 98 & 88 \\
\hline 3.0 & 100 & 82 & 81 & 100 & 102 & 93 \\
\hline 5.0 & 101 & 98 & 101 & 97 & 96 & 99 \\
\hline
\end{tabular}

the best recovery values for all pesticides. The pesticides recovery was also evaluated with different elution volumes (between 1 and $5 \mathrm{~mL}$ ). The elution with 3 or $5 \mathrm{~mL}$ of ethyl acetate promoted good recovery values (81-102\%) for all pesticides (Table 3). Table 4 displays the RSD of the experimental data obtained during the method development.

All validation studies were performed with pesticidefree fruits. The use of matrix-matched calibration standards was done to compensate the matrix effect observed previously for dimethoate, diazinon and fenitrothion. ${ }^{52}$

The literature data shows a common occurrence of pesticide residues in the fruit samples. $34 \%$ of the total fruits samples from Spain ${ }^{53}$ and $14.7 \%$ from China ${ }^{54}$ presented considerable concentrations of pesticides residues. $45.17 \%$ from Croatia, ${ }^{55}$ 68.5\% from Canada ${ }^{56}$ and $33.3 \%$ from Greece $^{57}$ were positive for at least one pesticide. $47.8 \%$ of Brazilian fruits, mainly apples, bananas, mangoes, melons, papayas and pineapples attested the presence of pesticide residues. ${ }^{58} \mathrm{~A}$ large number of the analytical methodologies described in the literature use chromatography coupled to mass spectroscopy to analyze pesticides residues. However, a methodology based on matrix solid-phase dispersion (MSPD) extraction followed by gas chromatography with electron-capture detection (GC-ECD) is scarce. The results presented in this work describe a simple extraction

Table 4. Relative standard deviation (RSD) of the experimental data obtained during the method development for the target pesticides ( $\mathrm{n}=5$ for each pesticide)

\begin{tabular}{|c|c|c|c|c|c|}
\hline & \multicolumn{5}{|c|}{ Relative standard deviation (RSD) / \% } \\
\hline & Chlorothalonil & Diazinon & Dimethoate & Fenitrothion & Parathion methyl \\
\hline \multicolumn{6}{|l|}{ Adsorbent (clean-up) } \\
\hline Alumina/florisil & 7.78 & 2.12 & 0.71 & 7.07 & 14.1 \\
\hline Alumina/celite & 23.3 & 26.9 & 14.8 & 2.83 & 0.71 \\
\hline Alumina/cellulose & 10.6 & 14.1 & 13.4 & 8.49 & 14.8 \\
\hline Alumina/silica gel & 14.1 & 11.3 & 12.0 & 10.6 & 7.78 \\
\hline Florisil/celite & 31.1 & 29.0 & 15.6 & 4.24 & 14.8 \\
\hline Florisil/cellulose & 2.83 & 12.0 & 14.1 & 1.41 & 0.71 \\
\hline Florisil/silica gel & 21.9 & 13.4 & 11.3 & 17.7 & 21.9 \\
\hline Celite/cellulose & 33.9 & 41.0 & 1.41 & 5.66 & 15.6 \\
\hline Celite/silica gel & 9.19 & 15.6 & 26.9 & 13.4 & 7.07 \\
\hline \multicolumn{6}{|l|}{ Solvent } \\
\hline Dichloromethane/ethyl acetate & 33.2 & 43.1 & 46.7 & 21.9 & 31.8 \\
\hline Dichloromethane/ethyl acetate/hexanoate & 28.3 & 5.7 & 20.5 & 17.0 & 18.4 \\
\hline Ethyl acetate/ethyl acetate/hexanoate & 28.3 & 5.7 & 20.5 & 17.0 & 18.4 \\
\hline
\end{tabular}


procedure followed by a standard chromatographic method to analyze the investigated pesticides in tropical fruits. Results are similar or better than that described in the literature using more complex and expensive approaches (such as SPE followed by GC-MS) for the same application.

\section{Conclusions}

The method described in this work provides a reliable and rapid quantitative analysis of five relevant pesticides residues in tropical fruit samples, based on MSPD extraction, followed by GC-ECD analysis. In the proposed MSPD procedure, the extraction (using $\mathrm{C} 18$ as dispersant) and clean-up (using silica gel) can be quickly performed in a single step requiring a low volume consumption of organic solvent in accordance to the green chemistry principles.

The analytical performance parameters showed that the proposed MSPD-GC-ECD method provides good results for selectivity, linearity, accuracy and precision. In addition, the LOD and LOQ values are below than the values required by both the Brazilian and WHO legislation. Since the proposed method presented similar results or better than the usual methods described in the literature, it can be used as a simple and reliable alternative for target pesticide residues analysis in the selected tropical fruit samples.

\section{Acknowledgments}

The authors are grateful to National Council for Scientific and Technological Development (CNPq, $307293 / 2014-9)$ for financial support provided to this research and to our laboratory.

\section{References}

1. http://www.seagri.ba.gov.br/sites/default/files/PDF\%20 Fruticultura_2017.pdf, accessed in March 2018.

2. http://www.bbc.com/news/business-30898966, accessed in April 2017.

3. http://www.thehindubusinessline.com/news/eus-import-ban-onindian-mangoes-comes-into-force/article5966383.ece, accessed in April 2017.

4. http://www.freshplaza.com/article/159105/French-pesticideban-hits-US-cherry-exports, accessed in April 2017.

5. https://www.wto.org/english/news_e/news16_e/ sps_03nov16_e.htm, accessed in March 2018.

6. Racke, K. D. In Pesticide Chemistry; Ohkawa, H.; Miyagawa, H.; Lee, P. W., eds.; Wiley-VCH Verlag GmbH \& Co. KGaA: Weinheim, Germany, 2007, ch. 4.

7. Boon, P. E.; Van der Voet, H.; Van Raaij, M. T. M.; Van Klaveren, J. D.; Food Chem. Toxicol. 2008, 46, 3090.
8. Caldas, E. D.; Boon, P. E.; Tressou, J.; Toxicology 2006, 222, 132.

9. Curl, C. L.; Fenske, R. A.; Elgethum, K.; Environ. Health Perspect. 2003, 111, 377.

10. Fenik, J.; Tankiewicz, M.; Biziuk, M.; Trends Anal. Chem. 2011, 30,814 .

11. Jardim, A. N. O.; Caldas, E. D.; Food Control 2012, 25, 607.

12. Chambers, J. E.; Carr, R. L.; Boone, J. S.; Chambers, H. W. In Handbook of Pesticides Toxicology; Krieger, R. I.; Krieger, W. C., eds.; Academic Press: London, 2001, ch. 45.

13. Edwards, F. L.; Tchounwou, P. B.; Int. J. Environ. Res. Public Health 2005, 2, 430.

14. Story, P.; Hooper, M. J.; Astheimer, L. B.; Buttemer, W. A.; Environ. Toxicol. Chem. 2011, 30, 1163.

15. Garber, K.; Steeger, T.; Risks of Dimethoate Use to the FederallyListed California Red Legged Frog (Rana aurora draytonii); Environmental Fate and Effects Division, Office of Pesticide Programs: Washington, D.C., 2008. Available at https://www3. epa.gov/pesticides/endanger/litstatus/effects/redleg-frog/ dimethoate/analysis.pdf, accessed on April 17, 2017.

16. Ghassempour, A.; Mohammadkhah, A.; Najafi, F.; Rajabzadeh, M.; Anal. Sci. 2002, 18, 779.

17. Roegge, C. S.; Timofeeva, O. A.; Seidler, F. J.; Slotkin, T. A.; Levin, E. D.; Brain Res. Bull. 2008, 75, 166.

18. World Health Organization (WHO); Environmental Health Criteria 198 - Diazinon; International Programme on Chemical Safety, WHO: Geneva, 1998. Available at http:// www.inchem.org/documents/ehc/ehc/ehc198.htm, accessed in April 2017.

19. Food and Agriculture Organization of the United Nations (FAO); Chlorothalonil; available at http://www.fao.org/fileadmin/ templates/agphome/documents/Pests_Pesticides/JMPR/ Evaluation97/Chlorot.PDF, accessed in April 2017.

20. Mozzachio, A. M.; Rusiecki, J. A.; Hoppin, J. A.; Mahajan, R.; Patel, R.; Beane-Freeman, L.; Alavanja, M. C. R.; Environ. Res. 2008, 108, 400 .

21. http://news.agropages.com/News/NewsDetail---14870.htm, accessed in March 2018.

22. Rigotto, R. M.; Vasconcelos, D. P.; Rocha, M. M.; Cad. Saúde Pública 2014, 30, 1360.

23. Lewis, K. A.; Tzilivakis, J.; Warner, D.; Green, J. A.; Human Ecol. Risk Assess. 2016, 22, 1050.

24. Abhilash, P. C.; Jamil, S.; Singh, N.; J. Chromatogr. A 2007, 1176, 43.

25. Abhilash, P. C.; Singh, V.; Singh, N.; Food Chem. 2009, 113, 267.

26. Criado, M. R.; Fernández, D. H.; Pereiro, I. R.; Torrijos, R. C.; J. Chromatogr. A 2004, 1056, 187.

27. Fernadez-Alvarez, M.; Llompart, M.; Lamas, J. P.; Lores, M.; Garcia-Jares, C.; Cela, R.; Dagnac, T.; J. Chromatogr. A 2009, 1216, 2832. 
28. Pugliese, P.; Moltó, J. C.; Damiani, P.; Marin, R.; Cossignani, L.; Mañes, J.; J. Chromatogr. A 2004, 1050, 185.

29. Ravelo-Pérez, L. M.; Hernández-Borges, J.; RodriguezDelgado, M. A.; J. Chromatogr. A 2008, 1211, 33.

30. Mastovska, K.; Wylie, P. L.; J. Chromatogr. A 2012, $1265,155$.

31. Nagarajan, G.; Khan, Z. S.; Utture, S. C.; Dasgupta, S.; Banerjee, K.; J. Chromatogr. A 2013, 1318, 226.

32. Qin, Y.; Zhang, J.; Zhang, Y.; Li, F.; Han, Y.; Zou, N.; Xu, H.; Qian, M.; Pan, C.; J. Chromatogr. A 2016, 1462, 19.

33. Valencia, G.; Llasera, M. P. G.; J. Chromatogr. A 2011, 1218 , 6869.

34. Asensio-Ramos, M.; Hernández-Borges, J.; Borges-Miquel, T. M.; Rodríguez-Delgado, M. A.; J. Chromatogr. A 2011, 1218, 4808.

35. de Pinho, G. P.; Neves, A. A.; de Queiroz, M. E. L. R.; Silvério, F. O.; Food Control 2010, 21, 1307.

36. Wua, J.; Lu, J.; Wilson, C.; Lina, Y.; Hai L.; J. Chromatogr. A 2010, $1217,6327$.

37. Abdulra'uf, L. B.; Tan, G. H.; Food Chem. 2015, 177, 267.

38. Tomkins, B. A.; Ilgner, R. H.; J. Chromatogr. A 2002, 972, 183.

39. Pintado-Herrera, M. G.; González-Mazo, E.; Lara-Martín, P. A.; Anal. Chim. Acta 2014, 851, 1.

40. Sánchez-Rojas, F.; Bosch-Ojeda, C.; Cano-Pavón, J. M.; Chromatographia 2009 69, 79.

41. Albero, B.; Sánchez-Brunete, C.; Miguel, E.; Tadeo, J. L.; Food. Chem. 2017, 217, 660.

42. Capriotti, A. L.; Cavaliere, C.; Foglia, P.; Samperi, R.; Stampachiacchiere, S.; Ventura, S.; Laganà, A.; Trends Anal. Chem. 2015, 71, 186.

43. Djatmika, R.; Chih-Chung, H.; Jhih-Ming, C.; Wang-Hsien, D.; J. Chromatogr. B 2016, 1036-1037, 93.

44. Jun, C.; Peng, L.-Q.; Xu, J.-J.; Du, L.-J.; Zhang, Q.-D.; J. Chromatogr. A 2016, 1477, 1.

45. Liu, H.; Kong, W.; Gong, B.; Miao, Q.; Qi, Y.; Yang, M.; J. Chromatogr. B 2015, 974, 65.
46. Salemi, A.; Shafiei, E.; Vosough. M.; Talanta 2012, 101, 504.

47. Agência Nacional de Vigilância Sanitária (ANVISA); Programa de Análise de Resíduos de Agrotóxicos em Alimentos (PARA); ANVISA: Brasília, 2014. Available at http://portal.anvisa. gov.br/documents/111215/117818/Relat\%25C3\%25B3ri o\%2BPARA \%2B 2012\%2B2\%25C2\%25AA\%2BEtapa\% 2B-\%2B17_10_14-Final.pdf/3bc220f9-8475-44ad-9d96cbbc988e28fa, accessed in April 2017.

48. Fajgelj, A.; Ambrus, A. In Principles and Practices of Method Validation.; Fajgelj, A.; Ambrus, A., eds.; Royal Society of Chemistry: Cambridge, 2000, ch. 10.

49. European Medicines Agency; Guideline on Bioanalytical Method Validation; European Medicines Agency: London, 2011. Available at http://www.ema.europa.eu/docs/en_GB/document_ library/Scientific_guideline/2011/08/WC500109686.pdf, accessed in April 2017.

50. Ferrer, C.; Martínez-Bueno, M. J.; Lozano, A.; Fernández-Alba, A. R.; Talanta 2011, 83, 1552.

51. Ministério da Agricultura, Pecuária e Abastecimento (MAPA); Manual de Garantia da Qualidade Analítica; MAPA: Brasília, 2015. Available at http://www.agricultura.gov.br/assuntos/ laboratorios/arquivos-publicacoes-laboratorio/manual-degarantia-qualidade-analitica.pdf, accessed in April 2017.

52. Freitas, S. S.; Lanças, F. M.; J. Sep. Sci. 2009, 32, 3698.

53. Blasco, C.; Font, G.; Pico, Y.; Food Control 2006, 17, 841.

54. Chen, C.; Qian, Y. Z.; Chen, Q.; Food Control 2011, 22, 1114.

55. Knezevic, Z.; Serdar, M.; Food Control 2009, $20,419$.

56. Ripley, B. D.; Lissemore, L. I.; Leishman, P. D.; Denomme, M. A.; Ritter, L.; J. AOAC Int. 2000, 83, 196.

57. Danis, T. G.; Karagiozoglou, D. T.; Tsakiris, I. N.; Alegakis, A. K.; Tsatsakis, A. M.; Food Chem. 2011, 126, 97.

58. Jardim, A. N. O.; Caldas, E. D.; Food Control 2012, $25,607$.

Submitted: January 10, 2018

Published online: March 7, 2018 